\title{
Case study of pancreas-preserving enucleation in the treatment of isolated pancreatic metastases of renal cell carcinoma
}

\author{
Toby D'cruz"* , JS Wong ${ }^{2}$ \\ From 4th International Conference for Healthcare and Medical Students (ICHAMS) 2014 \\ Dublin, Ireland. 24-25 October 2014
}

\section{Background}

Pancreatic metastases are rare, accounting for $2.8 \%$ of cases in RCC, occurring as a result of haematogenous spread to the pancreas. High affinity of some renal cancer cells for the pancreatic parenchyma present solely as isolated pancreatic metastases.

Literature reviews have highlighted that aggressive surgery for isolated pancreatic metastasis has been shown to increase 5 year survival rates unto $60 \%$; particularly nephrectomy \& metastasectomy with adjuvant therapy.

The objective of this case study was to identify the benefits of pancreas-preserving enucleation in treatment of isolated pancreatic RCC metastases over traditional pancreatic resections.

\section{Report}

Patient $\mathrm{X}$ was identified as a candidate for this case report.

$\mathrm{Mr} \mathrm{X}$. is a 77 year old fit and healthy male, presented with 2 day history of frank haematuria \& weight loss of $3 \mathrm{~kg}$ over 6 months with no associated fever, flank pain or dysuria. CT KUB revealed lobulated soft tissue density in the right kidney, suspicious for a tumour. Further staging investigations of CT TAP demonstrated a small enhancing nodule in pancreatic body confirmed as pancreatic metastasis with EUA FNA. The patient subsequently underwent Open Right Radical Nephrectomy with Enucleation of Pancreatic Metastasis.

\section{Discussion}

Comparisons drawn between Pancreatic-sparing Enucleations and standard resection (Complete Pancreatectomy)

'School of Medicine and Medical Sciences, University College Dublin, Dublin, Republic of Ireland

Full list of author information is available at the end of the article explore variations in surgical challenges \& post-operative complications. While there has been no difference in morbidity and recurrence noted compared to complete pancreatectomy; there has been significant reduction in post-operative diabetes mellitus.

\section{Conclusions}

Pancreatic resections are associated with high rates of morbidity and mortality. A reduction in operative risk following pancreatic surgery have been demonstrated, in recent times. As such, Pancreas-sparing Enucleation \& Enucleo-resection has been considered a worthy option. Preservation of pancreatic tissue allows for better quality of life without diabetes mellitus.

\section{Consent to publish}

The patient had signed a written consent for publication of this abstract on Pancreatic Metastases.

\section{Authors' details}

'School of Medicine and Medical Sciences, University College Dublin, Dublin, Republic of Ireland. ${ }^{2}$ Singapore General Hospital, Singapore.

\section{Published: 27 October 2015}

\section{References}

1. Nerli RB: Cytoreductive nephrectomy for metastatic renal cell carcinoma. Journal of the Scientific Society 2013, 40(2):64-67.

2. Pantuck AJ, Belldegrun AS, Figlin RA: Cytoreductive Nephrectomy for Metastatic Renal Cell Carcinoma: Is It Still Imperative in the Era of Targeted Therapy? Clin Cancer Res 2007, 13(2 Pt 2):693s-696s.

3. Youssif TA, Tanguay S: Nephrectomy is necessary in the treatment of metastatic renal cell carcinoma. Can Urol Assoc J 4(1):65-67.

4. Zerbi A, Pecorelli N: Pancreatic metastases: An increasing clinical entity. World J Gastrointest Surg 2010, 2(8):255-259.

5. Bassi C, Butturini G, Falconi M, Sargenti M, Mantovani W, Pederzoli P: High recurrence rate after atypical resection for pancreatic metastases from renal cell carcinoma. Br J Surg 2003, 90(5):555-559. 
6. Sellner F, Tykalsky N, De Santis M, Pont J, Klimpfinger M: Solitary and Multiple Isolated Metastases of Clear Cell Renal Carcinoma to the Pancreas: An Indication for Pancreatic Surgery. Ann Surg Oncol 2006, 13(1):75-85.

7. Thompson LD, Heffess CS: Renal cell carcinoma to the pancreas in surgical pathology material. Cancer 2000, 89(5):1076-1088.

8. Flanigan R, Mickisch G, Sylvester R, Tangen C, Van Poppel H, Crawford E: Cytoreductive Nephrectomy in Patients With Metastatic Renal Cancer: A Combined Analysis. J Urol 2004, 171(3):1071-1076.

9. Ballarin R, Spaggiari M, Cautero N, De Ruvo N, Montalti R, Longo C, et al: Pancreatic metastases from renal cell carcinoma: The state of the art. World J Gastroenterol 2011, 17(43):4747-4756.

10. Yazbek T, Gayet B: The Place of Enucleation and Enucleo-Resection in the treatment of Pancreatic Metastasis of Renal Cell Carcinoma. JOP 2012, 13(4):433-438.

11. Konstantinidis IT, Dursun A, Zheng H, Wargo JA, Thayer SP, Fernandez-del Castillo CR, et al: Metastatic Tumors in the Pancreas in the Modern Era. $J$ Am Coll Surg 2010, 211(6):749-753.

doi:10.1186/1753-6561-9-S7-A23

Cite this article as: D'cruz and Wong: Case study of pancreas-preserving enucleation in the treatment of isolated pancreatic metastases of renal cell carcinoma. BMC Proceedings 2015 9(Suppl 7):A23.

\section{Submit your next manuscript to BioMed Central and take full advantage of:}

- Convenient online submission

- Thorough peer review

- No space constraints or color figure charges

- Immediate publication on acceptance

- Inclusion in PubMed, CAS, Scopus and Google Scholar

- Research which is freely available for redistribution

Submit your manuscript at www.biomedcentral.com/submit 